\title{
JOURNAL.RU
}

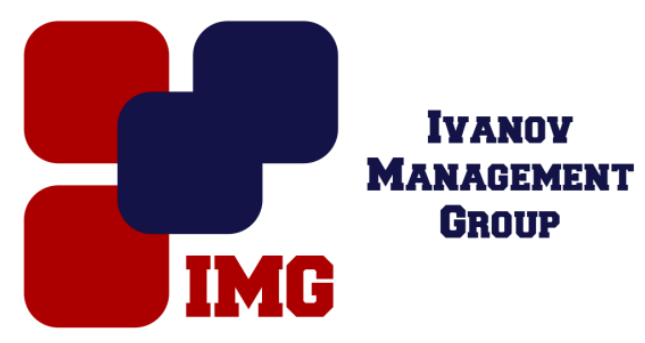

Ковальчук А.Е.

Московский государственный гуманитарно-экономический университет Москва, Россия

doi: 10.18411/lj-30-06-2017-15

idsp 000001:1j-30-06-2017-15

\section{Деятельность Международной АссоциацииИздателей и ее роль в процессах научной коммуникации}

\begin{abstract}
Аннотация
В статье рассматриваются основные направления деятельности Международной Ассоциации Издателей, как аккредитованной неправительственной организации, с точки зрения ее вклада в процесс обеспечения и развития формальных каналов научной коммуникации. Также, статья затрагивает вопрос самой научной коммуникации, как процесса на современном этапе развития информационного общества.

Ключевые слова: научные коммуникации, stm-книгоиздание, научноиздательская сфера.

Вторая половина двадцатого века ознаменовалась особенно бурным ростом и развитием информационных технологий, активно способствуя переходу от индустриального общества к обществу информационному. И действительно, можно сказать, что на современном этапе развития социума роль информации, во всем многообразии ее форм, является определяющей - чем большим объемом знаний и навыков обладает человек, тем выше становится его общественный и материальный статус.

На сегодняшний день информация - едва ли не самый важный ресурс, определяющий эффективность функционирования и обеспечения различных сфер человеческой деятельности, и право на доступ к объемам накопленной человечеством информации имеет жизненно важное значение для всех членов
\end{abstract}


общества. И если раньше процессы информационного обмена были в существенной степени затруднены из-за низкой скорости передачи данных между участниками коммуникационного процесса, то, благодаря развитию компьютерных технологий, сейчас этот обмен осуществляется фактически мгновенно не только на национальном, но и на международном уровне.

В связи с этим имеет смысл затронуть и вопросы научной коммуникации, как одну из важнейших составляющих информационного обмена. Итак, процессы научной коммуникации образуют важнейший компонент такого сложного социального явления, которое и называется наукой и изучение внутренних закономерностей которого на сегодняшний день является насущной необходимостью. Здесь следует отметить, что принято разграничивать процессы неформальной и формальной научной коммуникации и здесь подробнее следует остановиться именно на втором из обозначенных видов, поскольку именно он напрямую связан с закрепленностью различного вида научной информации на различного рода носителях. Причем, под носителями подразумеваются, как материальные объекты, так и информационная среда в целом. Основной особенностью, равно как и основным достоинством формальных процессов научной коммуникации является тот факт, что подавляющее большинство всей научной документации проходят через этап их публикации, что превращает зафиксированную на них информацию в информацию, по сути своей, постоянного хранения. К тому же, в процессе подготовки подобных публикаций материал тщательно оценивается с точки зрения его качества, достоверности, точности и, в целом, ценности содержащихся в нем сведений и распространение этих публикаций на международном уровне осуществляется за счет деятельности специализированных учреждений: издательств и издающих организаций.

В рамках рассматриваемой темы стоит подробнее остановиться на деятельности основных, на сегодняшний день, организаций, которые обеспечивают эффективность работы этих учреждений, представляя их интересы, а, следовательно, и поддерживая формальные коммуникационные процессы на международном уровне.

И важнейшей организацией в этом списке по праву может считаться Международная Ассоциация Издателей (International Publishers Association) аккредитованная неправительственная организация (НПО), выступающая в качестве консультанта в Организации Объединенных Наций. 
Именно МАИ является крупнейшим в мире объединением национальных и региональных ассоциаций издателей. В ее состав входят 70 организаций из 60 стран в Африке, Азии, Австралии, Европе и Америке. По совокупности, в ее деятельности принимает участие свыше 5,6 миллиардов человек по всему миру.

Головной офис ее располагается в Женеве, и основным родом деятельности ассоциации является представление интересов издательской индустрии.

МАИ была основана в Париже в 1896 году, и ее первоначальной задачей было осуществление контроля соблюдения авторских прав в масштабах мирового издательского рынка, а также за соблюдением принятой в 1886 году Бенской Конвенции. С самого первого года своего основания МАИ, в числе прочего, отстаивает свободу публикации, как одну из форм выражения основополагающего аспекта права человека на свободу слова.

Не реже, чем раз в год, во время проведения Франкфуртской книжной ярмарки собирается специализированный Международный комитет, в котором имеют своих представителей все ассоциации - члены МАИ.

Полномочным представителем и членом Международной Ассоциации Издателей в России является Ассоциация Книгоиздателей России (АСКИ).

Стоит отметить, что большое внимание международная ассоциация издателей уделяет вопросам продвижения и развития научной и научнотехнической литературы, которая является не только основной формой научной коммуникации, но и основой технического прогресса. Так, например, в рамках ассоциации ежегодно публикуется сборник STM-Report, в котором содержатся статистические данные о количестве существующих в мире научных издательств и научной периодики, а также аналитические данные о тенденциях и перспективахразвития научного книгоиздания в целом.

Именно благодаря аналитической деятельности МАИ становится возможным проследить изменения, происходящие в процессе системы научной коммуникации в целом.

Так, например, опираясь на данные МАИ можно выделить три основных направления, в которых, начиная с 2008 года, происходят изменения в системе научной коммуникации.

Первым направлением являются изменения на общемировом издательском рынке, посредством которого реализуются формальные коммуникационные методы: появляются новые деловые модели, подобные модели OpenAccess (система, в режиме реального времени обеспечивающая доступ пользователей к 
научным материалам посредством сети Интернет); формируются новые каналы продаж, как, скажем, продажи через консорциумы.

Вторым направлением можно считать изменения в самом процессе проведения научных исследований, напрямую связанные с развитием и ростом информационных сетей, возможностей быстрой обработки больших массивов данных и общей глобализацией исследований.

Третье же направление связано с изменениями государственной политики, касающиеся законов, регламентирующих авторское право и выделение мандатов финансирующих организаций по поводу архивирования и совместного использования данных.

Также благодаря деятельности МАИ можно составить представление о современных масштабах научного издательского рынка, который по данным аналитиков ассоциации продолжает неуклонно расширяться вот уже на протяжении трех сотен лет. Так, например, количество научных публикаций в рецензируемых научных изданиях ежегодно вырастает на 3,5\%.

Как уже упоминалось выше, МАИ поддерживает связи со многими международными организациями, имея официальный статус консультанта при Организации Объединенных Наций, включая Всемирную организацию интеллектуальной собственности (ВОИС), и Организацию Объединенных Наций по вопросам образования, науки и культуры (ЮНЕСКО).

В связи с этим стоит отдельно отметить и деятельность этих организаций. Поскольку ООН является одной из крупнейших издающих организаций мира, обеспечивая не только работу Генеральной Ассамблеи и заседаний Совета Безопасности в Нью-Йорке, но и курирует развитие и обеспечение таких отраслей науки, как здравоохранение (подразделение ООН в Женеве) или атомная энергетика (подразделение в Вене).

ЮНЕСКО, наряду с оказанием помощи в развитии книгоиздания по всему миру, в свою очередь, также ведет активную издательскую деятельность, способствующую процессам информационного обмена в обществе.

Эта организация осуществляет свою деятельность сразу в нескольких направлениях:

1. Ведет научно-просветительскую деятельность в развивающихся регионах мира, таких, как Азия, Африка и Латинская Америка, уделяя внимание вопросам ликвидации безграмотности и пропаганды чтения.

2. Ведет статистический учет издательской продукции. 
3. Массово выпускает периодику по разным направлениям и отраслям знания.

Таким образом, рассматривая деятельность международных издательских ассоциаций и объединений с точки зрения их влияния на процессы научной коммуникации, можно сделать вывод, что тенденции глобализации научных процессов и, как следствие, необходимость создания единой информационной среды, позволяющей осуществлять оперативный обмен данными на межконтинентальном уровне, не в последнюю очередь зависят именно от эффективного функционирования подобных организаций. Процессы формальной научной коммуникации, предполагающие документальную фиксацию научного знания в различных формах публикаций, таких, как статьи, монографии, сборники материалов конференций и т.д. немыслимы без активно действующей глобальной системы издательского дела, развитию которого способствуют международные издательские объединения.

1. International Publishers Association: [Электронныйресурс]. France, 2014. URL: https://www.internationalpublishers.org/. (Дата обращения 05.06. 2017)

2. Зельдина M.M. STM Report 2015: краткое содержание // Научная периодика: проблемы и решения. — 2016. — Том 6. — № 1. — c. 4-26. — doi: 10.18334/nppir.6.1.35040

3. Гиляревский Р.С. Информатика и библиотековедение [Текст] : общие тенденции в развитии и преподавании / Р. С. Гиляревский ; АН СССР, ВИНИТИ. - Москва: Наука, 1974. - 200, [3] с. 